\title{
EVALUASI PROGRAM PEMBELAJARAN SAINTIFIK
}

\section{EVALUATION OF SAINTIFIC LEARNING PROGRAM}

\author{
NS Fatimah'1a, H Bisri1 ${ }^{1}$ dan M Ichsan'1 \\ ${ }^{1}$ Program Studi Pendidikan Guru Sekolah Dasar, Fakultas Keguruan Ilmu Pendidikan, Universitas \\ Djuanda Bogor, Indonesia \\ a Korespondensi: Nurul Suci Fatimah, Email: nurul.suci.fatimah@unida.ac.id \\ (Diterima: 10-02-2019; Ditelaah: 11-02-2019; Disetujui: 27-03-2019)
}

\begin{abstract}
One of the government's policies for the education sector that now must be implemented by every school is using the 2013 curriculum, especially for the elementary school level of education. There are many approaches that can be used in basic and secondary education. This study did at SDIT Raudlatul Jannah that has a learning program using a scientific approach. This research used qualitative approach by type of evaluation research with Stake Model. Data were collected through observation techniques, interviews, questionnaires, and documentation studies. Data analysis techniques were done through data reduction, display data, and verification. The result of the study showed that the context aspect (antecedent) base or implementation of learning program of scientific approach in SDIT Raudlatul Jannah is in line with the regulation of minister of education and culture No. 103 year 2014 article 2 verse 7. Transactional aspect of transaction evaluation of scientific approach in SDIT Raudlatul Jannah 85\% has met the criteria. Output aspect based on average KKM's achievement, student's SME scores, and students' effective student-level outcomes are good.
\end{abstract}

Keywords: program evaluation, stake, learning, scientific approach.

\begin{abstract}
ABSTRAK
Salah satu kebijakan pemerintah bagi dunia pendidikan yang sekarang harus diaplikasikan oleh setiap sekolah yaitu penggunaan kurikulum 2013, terutama bagi satuan tingkat pendidikan Sekolah Dasar. Ada banyak pendekatan yang dapat digunakan dalam pembelajaran pada pendidikan dasar dan menengah. Penelitian ini dilaksanakan di SDIT Raudlatul Jannah yang memiliki program pembelajaran dengan menggunakan pendekatan saintifik. Penelitian ini menggunakan pendekatan kualitatif dengan jenis penelitian evaluasi dengan Model Stake. Data dikumpulkan melalui teknik observasi, wawancara, kuesioner, dan studi dokumentasi. Teknik analisis data dilakukan melalui reduksi data, data display, dan penarikan kesimpulan atau verifikasi kesimpulan. Hasil penelitian menunjukkan bahwa aspek konteks (antecedent) landasan atau dasar pelaksanaan program pembelajaran pendekatan saintifik di SDIT Raudlatul Jannah sejalan dengan peraturan menteri pendidikan dan kebudayaan no 103 tahun 2014 pasal 2 ayat 7. Aspek proses (transaction) hasil evaluasi terhadap kesesuaian program pembelajaran pendekatan saintifik di SDIT Raudlatul Jannah 85\% sudah memenuhi kriteria. Aspek keluaran (output) berdasarkan ketercapaian KKM di atas rata-rata nilai UKK siswa dan hasil ranah efektif siswa secara keseluruhan baik.
\end{abstract}

Kata kunci: evaluasi program, stake, pembelajaran, pendekatan saintifik. 
Fatimah, N. S., Bisri, H., \& Ichsan, M. (2019). Evaluasi Program Pembelajaran Saintifik. Didaktika Tauhidi: Jurnal Pendidikan Guru Sekolah Dasar, 6(1): 57-72.

\section{PENDAHULUAN}

K13 atau Kurikulum 2013 dengan mengaplikasikan pendekatan saintifik ini tidaklah mudah. Guru harus membuat prepare yang matang, guru mampu mengelola pembelajaran dengan profesional, dan guru membutuhkan inovasi pembelajaran dalam menerapkannya. Hal ini pula merupakan hasil dari penelitian Krisandi \& Rusmawan (2015) bahwa ada beberapa hal yang menjadi kendala bagi guru dalam menerapkan K13 yaitu kurangnya keterampilan guru dalam membuat media pembelajaran, pemahaman guru terhadap materi, kurangnya pengetahuan guru dalam memadukan pembelajaran tematik, dan keahlian guru di bidang komputer. Walaupun demikian, survei terbatas tentang kesiapan guru dalam menghadapi K13 yang dilakukan oleh guru SD di Yogyakarta rata-rata menunjukkan kesiapan di atas 70\% dengan kategori Siap dan Sangat Siap (Wangid, Mustadi, Erviana, \& Arifin, 2014).

Selain itu, berdasarkan wawancara dengan wali kelas di SDIT Raudlatul Jannah, tidak mudah mengubah pola pikir siswa untuk mempunyai kemauan dan kebiasaan berlatih, contohnya belajar mandiri, berdiskusi, melakukan eksperimen, dan lain-lain. Implementasinya belum merata, namun pemilik kebijakan terus berupaya dengan segala macam cara untuk menciptalan perubahan yang signifikan dengan kurikulum 2013. Dalam hal ini perlu pula adanya setrategi kepemimpinan pembelajaran meliputi keteladanan dari pemimpin, membiasakan melakukan pembelajaran tidak hanya di dalam kelas namun juga di luar kelas, memperbaiki kultur sekolah, dan penguatan kepada siswa dan guru untuk terus meningkatkan prestasi (Usman \& Raharjo, 2013).

Pada semester ganjil tahun ajaran 20162017 berdasarkan hasil wawancara bersama seorang guru bernama Bapak Saiful, menyebutkan SDIT Raudlatul Jannah mencapai $\quad 80 \%$ dalam tingkat keberhasilannya. Dari aspek guru sudah dilaksanakan, siswa sudah mengikuti dan sarana pembelajaran juga sudah cukup mendukung. Akan tetapi dalam aspek lain masih terdapat kendala dengan presentase $20 \%$, hal ini penyebabnya karena kurang fokus siswa dalam proses menggali ilmu, adanya beberapa siswa yang belum terbuka sehingga guru sulit untuk melihat perkembangannya. Akan tetapi pihak sekolah terus berusaha melakukan beberapa solusi untuk meminimalisisr hambatan tersebut seperti memberi motivasi lebih, teguran, serta memberikan waktu bergantian untuk lebih aktif.

Didasari paparan di atas, dalam upaya mengetahui capaian kesuksesan pelaksanaan program ini mewajibkan gurunya melakukan pembelajaran menggunakan berbagai pilihan pendekatan dimana pelaksanaan dari pendekatan tersebut diwajibkan melakukan ulasan terhadap program tersebut. Guru dikatakan profesional bila mampu memilih pendekatan, model, metode, strategi atau teknik yang tepat dalam pembelajaran. Guru selaku seorang pendidik seharusnya bisa dan mampu memotivasi, mengaktifkan, dan membimbing siswa serta mengajak untuk berpartisipasi secara aktif sehingga kompetensi siswa (kecakapan hidup) dapat berkembang (Sesrita, 2017). Sebenarnya kompetensi pedagogik dan profesional guru 
dalam melaksanakan pendekatan saintifik sudah dalam kategori baik (Wulandari \& Mundilarto, 2016), namun memang harus ada penelitian lebih luas lagi tentang kemampuan guru ini.

Oleh sebab itu penelitian ini dilakukan sebagai upaya untuk menyelenggarakan ulasan terhadap rancangan pembelajaran menggunakan pendekatan saintifik di Sekolah Dasar Islam Terpadu Raudhatul Jannah Ciawi Kabupaten Bogor. Dalam pelaksanaannya banyak komponen terkait, diantaranya: (1) proses pembelajaran; (2) guru; (3) peserta didik; (4) metode mengajar; (5) kurikulum; (6) media pembelajaran; dan (7) evaluasi belajar.
Berdasarkan pokok dan subpokok yang telah dituliskan, maka dilakukan orientasi evaluasi sebagai berikut: (1) untuk mengevaluasi antesenden/konteks (antecedents/context); (2) untuk mengevaluasi transaksi/proses (transaction/process); dan (3) untuk mengevaluasi keluaran (output).

\section{METODE}

Pendekatan penelitian kualitatif jenis penelitian evaluasi. Model evaluasi yang digunakan yaitu Model Stake (countenance model). Seterusnya disuguhkan countenance matrix pada Tabel 1.

Tabel 1 Countenance matrix

\begin{tabular}{|c|c|}
\hline Tahap & Aspek \\
\hline \multirow[t]{6}{*}{ Antecedent } & $\begin{array}{l}\text { Landasan dasar, tujuan, manfaat, dan sasaran program pembelajaran } \\
\text { pendekatan saintifik }\end{array}$ \\
\hline & Person yang terikat program pembelajaran pendekatan saintifik \\
\hline & Kriteria dan prasyarat guru \\
\hline & Konstruk program pembelajaran pendekatan saintifik \\
\hline & Fasilitas penunjang program pembelajaran pendekatan saintifik \\
\hline & $\begin{array}{l}\text { Waktu Pelaksanaan program dan persiapan yang dilakukan sekolah } \\
\text { sebelum melakukan program }\end{array}$ \\
\hline \multirow[t]{5}{*}{ Transaction } & $\begin{array}{l}\text { Persiapan administrasi guru seperti Silabus, RPP, Promes, Prota, dan bahan } \\
\text { ajar }\end{array}$ \\
\hline & $\begin{array}{l}\text { Proses pelaksanaan program pembelajaran pendekatan saintifik } \\
\text { (mengamati, menanya, mencoba/mengumpulkan informasi, } \\
\text { menalar/asosiasi, dan komunikasi) }\end{array}$ \\
\hline & Pendekatan, media, metode, dan model \\
\hline & Pengetahuan siswa secara spesifik \\
\hline & Penilaian proses siswa, produk, dan sikap \\
\hline \multirow[t]{5}{*}{ Output } & Kompetensi yang dicapai siswa \\
\hline & Perolehan menggali ilmu siswa di atas KKM \\
\hline & Penilaian pembelajaran pendekatan saintifik \\
\hline & Hambatan dan pendukung program \\
\hline & Performa murid dan sekolah \\
\hline
\end{tabular}




\section{Tempat dan Waktu Penelitian}

Riset ini diteliti di Sekolah Dasar Islam Terpadu Raudhatul Jannah Kecamatan Ciawi Kabupaten Bogor yang beralamat di Jl. Veteran III Rt. 03/03, Desa Banjarwangi Kecamatan Ciawi Kabupaten Bogor. Penelitian dilakukan saat bulan JanuariApril 2017 sejak dimulainya observasi awal penelitian.

\section{Subjek Penelitian Evaluasi}

Subjek penelitian ialah pembesar sekolah, guru, dan siswa di SDIT Raudlatul Jannah selaku sekolah yang mewajibkan adanya program pembelajaran pendekatan saintifik. Sumber data tersebut terdapat pada Tabel 2.

Tabel 2 Jenis responden yang digunakan

\begin{tabular}{llr}
\hline No & Nama Responden & Jumlah \\
\hline 1 & Kepala Sekolah & 1 \\
2 & Wali Kelas & 4 \\
3 & Pengawas Sekolah & 1 \\
4 & Staff Yayasan & 1 \\
5 & Ka. Tata Usaha & 1 \\
6 & Siswa & 6 \\
\hline
\end{tabular}

\section{Teknik Pengumpulan Data}

Teknik pengumpulan data menjadi langkah yang strategis dalam proses penelitian sebagai penghimpun data. Pengumpulan data dilakukan dengan wawancara, kuesioner, observasi, dan stusi dokumentasi.

\section{Wawancara}

Wawancara ialah ragam evaluasi yang bukan tes bisa dilakukan melalui soal-soal dan tanggapan dari satu pihak, dua pihak atau lebih. Dengan menggunakan servis yang ada berupa pertemuan wajah atau bertemu langsung atau dengan adanya bantuan media elektronik, media online, dan memerlukan bantuan internet. Contohnya wawancara atau percakapn melalui telpon, video call, dan lain-lain. Wawancara ini menggunakan panduan wawancara. Informan bertemu tanpa perantara untuk menemukan dan menggali sumber informasi. Tanya jawab dilakukan dengan rujukan yang memang terpercaya dan direkomendasikan oleh pihak informan (Moleong, 2013). Peneliti meng-interview pejabat sekolah, pengajar, peninjau sekolah, yayasan, kepala manajemen tadbir, dan siswa.

\section{Kuesioner}

Kuesioner ditunaikan via formasi pernyataan atau pertanyaan melalui tulisan kepada subjek penelitian dan kemudian diambil jawabannya (Sugiyono, 2016). Peneliti memberikan kuesioner kepada pemimpin sekolah, guru, pengawas sekolah, dan staf yayasan.

\section{Observasi}

Observasi menjadi bagian panjang proses mengamati, dan hasilnya digunakan untuk dicatat secara berurutan dan rapih berdasarkan aktualitas sesungguhnya, tetapi hasilnya harus masuk akal yang dapat dipersentasikan terkait perkara yang kita deskripsikan dengan shahih/valid (Sugiyono, 2016). Tujuan utama observasi penelitian ini adalah menggali data dan berita yang akan direduksi dan disintesis menjadi puncak evidensi peneliti dalam melanjutkan penelitian untuk meraih keuntungan yang diidamkan. Hal yang diobservasi secara umum adalah sarpras pembelajaran saintifik di kelas, keadaan lingkungan sekolah, proses perencanaan, 
proses pelaksanaan, dan evaluasi pembelajaran saintifik di kelas. Lebih lengkap indikatornya disajikan pada Tabel 3.

Tabel 3 Indikator yang diobservasi berdasarkan jenis responden

\begin{tabular}{ll}
\hline \multicolumn{1}{c}{ Jenis } & \multicolumn{1}{c}{ Indikator } \\
Responden & \\
\hline Kepala & a. Sarana dan prasarana \\
Sekolah & sekolah dan kelas \\
& b. Keadaan lingkungan \\
& sekolah dan kelas \\
& c. Perencanaan program \\
& d. Pelaksanaan program \\
& e. Penilaian program \\
& f. Evaluasi program \\
Guru & a. Perangkat administrasi \\
& guru \\
& b. Perencanaan program \\
& c. Pelaksanaan program \\
& d. Penilaian program \\
& e. Evaluasi program \\
Siswa & a. Persiapan perlengkapan \\
& belajar siswa \\
& b. Kelompok belajar siswa \\
& c. Keaktifan siswa \\
& d. Komunikasi dua arah \\
& e. Pemahaman akhir siswa \\
& f. Hasil belajar siswa \\
&
\end{tabular}

\section{Studi Dokumentasi}

Studi dokumen berkaitan dengan penelitian mengenai dokumen. Dokumen ini adalah informasi yang tercetak dan terekam dalam media, misalnya buku dan surat. Dokumen merupakan catatan peristiwa yang berbentuk surat kabar, majalah, kaset, disk, film, slide, microfilm, mikroopak, peta, dan sebagainya (Wirawan, 2012). Studi dokumentasi dilakukan dengan mengumpulkan berkas-berkas terkait evaluasi program pembelajaran saintifik di sekolah yang disiapkan.

Setelah dijelaskan mengenai teknik pengumpulan data yang digunakan, berikut dirangkum teknik pengumpulan data berdasarkan jenis responden pada Tabel 4 .

Tabel 4 Teknik pengumpulan data berdasarkan responden

\begin{tabular}{|c|c|c|}
\hline No & Cara & Responden \\
\hline 1 & Wawancara & $\begin{array}{l}\text { Kepala Sekolah, Guru, } \\
\text { Pengawas Sekolah, } \\
\text { dan Siswa }\end{array}$ \\
\hline 2 & Kuesioner & Guru \\
\hline 3 & Observasi & $\begin{array}{l}\text { Guru, Siswa, dan } \\
\text { Sekolah }\end{array}$ \\
\hline 4 & Dokumentasi & $\begin{array}{l}\text { Kepala Sekolah, Guru, } \\
\text { Pengawas Sekolah, } \\
\text { dan Bagian TU }\end{array}$ \\
\hline
\end{tabular}

\section{Validitas Dan Reliabilitas}

\section{Validitas Instrumen}

Validitas merupakan aturan tetap yang mustahil sanggup dimanipulasi antara data yang diperoleh dan terjadi pada perkara penelitian dengan data yang dibawa dan dituliskan oleh peneliti. Untuk itu data yang otentik adalah data "yang tidak berbeda" (Sugiyono, 2016). Penelitian ini menggunakan uji validitas isi, dimana cara menguji validitasnya menggunakan pendapat para pakar (judgement experts). Kuesioner akan diuji oleh para ahli yaitu dosen. Jumlah validator yaitu minimal 2 orang. Pada angket itu ada perbaikan oleh dosen atau ahli pada pertanyaan yang disajikan. 


\section{Reliabilitas Instrumen}

Tahap ini digunakan untuk memeriksa keabsahan data untuk menjauhkan kekeliruan analisis data. Demi menghasilkan data yang tepat dipakai teknik triangulasi yaitu: (1) Triangulasi teknik, peneliti menggunakan cara pengumpulan data dengan banyak bentuk tetapi sumber data yang dicari sama. Peneliti menggunakan wawancara mendalam, kuesioner, observasi terstruktur, dan dokumentasi; (2) Triangulasi sumber data, data didapatkan dari ahli yang banyak dengan teknik yang sama. Peneliti memperoleh dari beberapa sumber seperti kepala sekolah, kepala tata usaha, guru, siswa, pengawas sekolah, dan yayasan.

\section{Analisis Data}

Menurut Miles dan Huberman, kegiataan analisis data kualitatif dilaksanakan secara dua arah dan berlangsung tidak terputus, sehingga datanya jenuh (Sugiyono, 2016). Data yang jenuh data yang benar-benar lengkap mengakar sampai porosnya, sehingga semua data telah terkumpul. Aktivitasnya yaitu reduksi data (data reduction), penyajian data (data display), dan penarikan kesimpulan (conclusion drawing/verification) digambarkan pada Gambar 1.

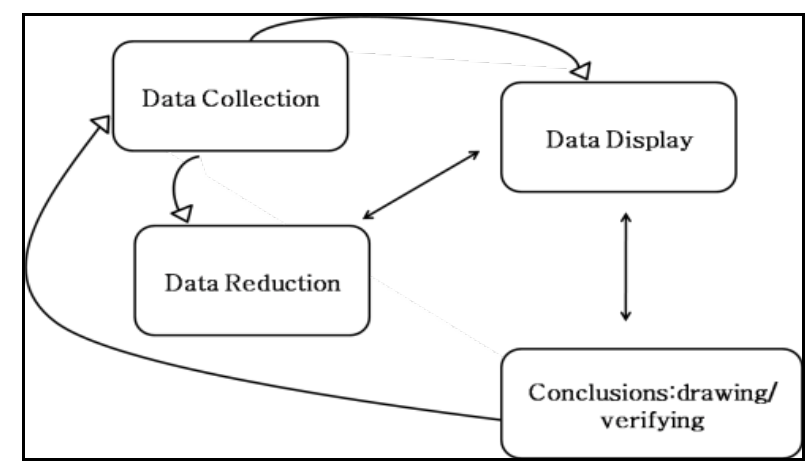

Gambar 1 Elemen dalam analisis data (interactive model)

Data reduction, kegiatan mereduksi dilakukan dengan cara memilih beberapa dari seluruh alternatif yang ada. Caranya adalah dengan menyortir data sehingga memudahkan peneliti untuk melakukan pengumpulan data selanjutnya. Kemudian data display, merupakan data yang ditampilkan dalam pemaparan data kualitatif yang berbentuk narasi. Dan cnnclusion drawing/verification, ini merupakan tahap terakhir yang berisi pencabutan konklusi dan pemeriksaan ulang.

\section{HASIL DAN PEMBAHASAN}

\section{Aspek Konteks (Antecedent) Evaluasi Program Pembelajaran Saintifik}

Hasil evaluasi pada aspek ini terdiri dari sub-evaluasi landasan dasar program, tujuan program, manfaat program, sasaran program, SDM, dan peralatan penunjang.

\section{Landasan Dasar Program Pembelajaran Pendekatan Saintifik}

SDIT Raudlatul Jannah, sebagai sekolah yang telah menerapkan Kurikulum 2013 pada kelas 1 dan 4 dengan menggunakan program pembelajaran pendekatan saintifik, telah menggunakan Kurikulum 2013 selama 4 tahun sejak dikeluarkannya kurikulum 2013. Landasan program ini dilaksanakan sesuai dengan peraturan yang sudah diketuk palu oleh pemerintah, pembelajaran pendekatan saintifik berdasarkan Permendikbud No 103 Tahun 2014 pasal 2 ayat 7.

Pengawas sekolah SDIT Raudlatul Jannah, Ibu Wahyu Kurniawati menyatakan bahwa tambahan terhadap landasan dasar program mengenai kurikulum 2013 dari pemerintah itu merupakan program satu gugus. Kecamatan Ciawi harus ada satu gugus yang didahulukan menggunakan kurikulum 2013, kemudian kepala UPT menawarkan SDIT 
Raudlatul Jannah sebagai tempat pengaplikasian. Pertimbangan beliau adalah karena Ibu Wahyu Kurniati sebagai pengawas sudah didiklat dan dilatih di Bandung tentang kurikulum 2013. Sehingga gugus binaannya dijadikan sebagai percontohan untuk gugus-gugus di sekolah lain, yang namanya gugus Teluk Pinang. Gugus Teluk Pinang terdiri dari 8 sekolah yaitu SDN Teluk Pinang 1, SDN Teluk Pinang 2, SDN Teluk Pinang 3, SDIT Raudlatul Jannah, SD Swasta Arrofi'iah, SDN Banjar Sari 2, SDN Cibedug 1, dan SDN Cibedug 3.

Hal tersebut yang menjadi penguat landasan dasar SDIT Raudlatul Jannah dalam melaksanakan program pembelajaran pendekatan saintifik. Jumlah peserta program tahun 2016/2017 seluruhnya berjumlah 161 orang, dengan rincian kelas 1 berjumlah 84 orang terbagi menjadi 44 anak pria dan 40 orang wanita, sedangkan di kelas 4 berjumlah 77 orang 41 orang pria dan 36 orang wanita. Kristiantari (2014) mencatat, guru-guru Sekolah Dasar telah siap dalam menghadapi Kurikulum 2013 dan mereka memiliki harapan yang tinggi terhadap tugas baru yang akan diemban.

\section{Tujuan Program Pembelajaran Pendekatan Saintifik}

Tujuan ini diperoleh oleh peneliti berdasarkan hasil kuesioner kepala sekolah dan guru. Wawancara dengan kepala sekolah tujuannya dirumuskan menjadi: Pertama, program bertujuan untuk meningkatkan kapasitas keilmuan atau kemampuan intelektual siswa khususnya kesanggupan berpendapat tingkat tinggi yang tertanam dalam siswa. Tujuan ini untuk menunjukkan kemampuan siswa dalam mencapai kemampuan menerapkan konsepsi atau prinsipil dalam setiap mata pelajaran yang belum atau telah disiswai siswa. Selain siswa juga harus dapat menganalisis dan mensintesis sebuah konsep atau prinsip tersebut.

Kedua, melatih keterampilan proses berpikir ilmiah siswa melalui mengamati, menanya, mencoba atau mengumpulkan informasi, mengasosiasi atau menalar, mengkomunikasikan. Tujuan ini untuk menciptakan siswa aktif dalam mengamati objek/materi yang disiswai sesuai dengan kode yang telah diberikan guru sebagai fasilitator, siswa juga memerankan tugas dengan aktif dalam bertanya kepada guru, siswa juga mampu melihat pola yang tepat dalam menentukan informasi yang didapat, siswa mampu menarik kesimpulan yang tepat dalam kegiatan pembelajaran serta bukan hanya itu siswa harus responsive dalam mengkomunikasikan. Seperti halnya penelitian yang menerapkan pendekatan saintifik terhadap siswa yang dilakukan oleh Tureni (2014).

Ketiga, mengembangkan karakter siswa. Karakter siswa itu harus dikembangkan dengan baik khususnya karakter positif, beraneka macam sosok positif yang dapat dikembangkan beberapa diantaranya karakter teliti, kuriositas yang tinggi, percaya diri, disiplin dan lain-lain. Diantaranya pula kegiatan ini dapat meningkatkan kepercayaan siswa dalam berargumentasi (Siswanto, Kaniawati, \& Suhandi, 2014).

Keempat, mendorong minat belajar siswa. Minat belajar siswa harus selalu didukung karena bukan siswa yang malas melainkan guru yang harus tau bagaimana cara mengembangkan setiap potensial yang dimiliki siswa khususnya dalam mengoptimalkan kesukaan dan kebolehan siswa dalam pembelajaran. Potensi ini perlu ditingkatkan dengan menerapkan 
pembelajaran yang sejalan dengan Kurikulum 2013 seperti pembelajaran realistik dan pembelajaran saintifik (Wibowo, 2017).

\section{Manfaat Program Pembelajaran Pendekatan Saintifik}

Manfaat ini diperoleh oleh peneliti berdasarkan hasil kuesioner kepala sekolah, pengawas sekolah, staff yayasan, dan guru. Juga diperoleh berdasarkan hasil wawancara dengan kepala sekolah, guru, pengawas sekolah, dan siswa. Manfaat tersebut dirumuskan oleh peneliti menjadi yaitu: Pertama, terciptanya pembelajaran yang aktif, kreatif, dan menyenangkan. Pembelajaran yang tangkas, imajjinatif, dan membahagiakan tidak bisa hanya diciptakan oleh satu pihak tetapi harus ada kerja tim yang baik oleh beberapa pihak yang terlibat maupun tidak terlibat misalnya tali silaturahim yang erat antara guru dengan siswa, sesama guru, sesama siswa, guru dengan orang tua, orang tua dengan kepala sekolah, kepala sekolah dengan guru, kepala sekolah dengan komite sekolah, komite sekolah dengan orang tua, kepala sekolah dengan pengawas sekolah dan yang penting juga harus ada komunikasi intens antara pihak sekolah dengan masyarakat. Relevansinya yaitu guru dan siswa harus berbagi pengalaman, sesama siswa harus saling mendukung satu sama lain, guru dengan orang tua harus melaporkan setiap perkembangan siswa di sekolah ataupun di rumah, orang tua harus memberikan masukan kepada pihak sekolah sehingga berperan aktif dalam melaksanakan dan merespon setiap kebijakan sekolah, sehingga adanya keselarahan cita-cita.

Kedua, terciptanya kemampuan berpikir ilmiah peserta didik. Menciptakan kemampuan berpikir ilmiah kepada peserta didik bukan merupakan hal yang mudah, ini memerlukan latihan secara terus menerus, tidak cepat berputus asa dengan kegagalan yang dialami, mewujudkan suasana belajar yang interaktif sehingga pengetahuan keliru yang dipikirkan siswa mampu diluruskan oleh guru. Siswa mampu menyelesaikan masalah dalam kehidupan sehari-hari secara sistematis sesuai dengan nilai dan norma yang telah ditetapkan. Dengan dibiasakan berpikir secara ilmiah, maka siswa dapat dengan mudah meningkatkan kemampuan kognitif dan kemampuan berargumentasi (Siswanto, Kaniawati, \& Suhandi, 2014).

\section{Sasaran Program Pembelajaran Pendekatan Saintifik}

Sasaran program ini adalah untuk peserta didik dalam menciptakan kolaborasi pada tiga ranah penilaian pembelajaran yaitu kognitif atau penilaian produk, afektif atau penilaian sikap, dan psikomotorik atau penilaian proses. Penilaian produk atau ranah kognitif berupa pemahaman konsep, prinsip, dan hukum dilakukan dengan tes tulisan maupun lisan. Penilaian produk bisa berupa keterampilan siswa, unjuk kerja siswa, hasil tes siswa, segala bukti fisik yang dihasilkan, dan lain-lain. Penilaian ranah psikomotorik, dilakukan melalui pemantauan saat siswa belajar dengan metode berkelompok, bekerja individu, berdiskusi, maupun saat presentasi. Penilaian sikap atau ranah afektif, melalui observasi saat siswa bekerja kelompok, bekerja individu, berdiskusi, maupun saat mempresentasikan dengan menggunakan lembar observasi sikap.

\section{SDM Program Pembelajaran Pendekatan Saintifik}

Berdasarkan hasil kuesioner guru, wawancara dengan kepala sekolah, dan pengawas sekolah, bahwa guru yang akan 
mengajar sudah terlatih dan dipersiapkan secara maksimal oleh pihak sekolah. 100\% guru di kelas satu dan empat SDIT Raudlatul Jannah sudah mengikuti pelatihan kurikulum 2013 sebanyak 6 orang. Kriteria dan prasyarat guru untuk mempersiapkan, telah dilakukan pelatihan sebanyak 2 kali, yaitu: (1) Pelatihan guru kelas 1 dan 4 pelaksana kurtilas yang dilaksanakan oleh Diknas kabupaten Bogor, di SDIT Raudlatul Jannah pada tanggal 6 - 8 Juni 2016; dan (2) Pelatihan guru "Penerapan Pembelajaran saintifik di Sekolah" di SDIT Raudlatul Jannah pada tanggal 22 September 2016, diiselenggarakan oleh LPIT yayasan Nurul Arroudlotul Jannah.

Dalam melaksanaan pembelajaran saintifik guru disyaratkan: memahami pembelajaran tematik terpadu, menguasai berbagai pendekatan pembelajaran, memahami hakikat, tujuan, dan prinsipprinsip pendekatan saintifk, memahami prosedur implementasi pendekatan saintifik, memiliki keterampilan dalam mengelola pembelajaran saintifik, melakukan persiapan secara matang dalam berbagai langkah yang ditampilkan dalam pembelajaran, berupa; materi yang akan disukai, metodologi, alat dan bahan, langkah pembelajaran, evaluasi, memiliki kemampuan mengatur, mengarahkan dan memfasilitasi belajar siswa, memiliki kemampuan mengevaluasi proses dan hasil belajar. Guru juga selayaknya mampu mengimplementasikan model pembelajaran yang sejalan dengan Kurikulum 2013 pada pembelajaran, seperti halnya pengembangan perangkat pembelajaran discovery learning pada pembelajaran saintifik yang dilakukan oleh Rudyanto (2014).

\section{Peralatan Penunjang Program Pembelajaran Pendekatan Saintifik}

Sarana dan prasarana itu diperlukan dalam segala aspek penilaian karena mendukung akan puncak impian yang maksimal. Terutama sarana dan prasarana dalam mendorong tercapainya tujuan pembelajaran secara optimal yaitu diantaranya meliputi: lapangan sekolah, kebun sekolah, lcd proyektor, laptop, pengeras suara, laboratorium IPA, ruang multimedia, laboratorium komputer, perpustakaan sekolah, unit kesehatan sekolah, peralatan olahraga, dan peralatan kesenian. Perbandingan tentang hasil penelitian pada kondisi obyektif dengan standar yang ada dapat dilihat pada Tabel 5 .

Tabel 5 Perbandingan hasil penelitian kondisi obyektif dengan standar yang ada

\begin{tabular}{|c|c|c|c|c|}
\hline No & Indikator & Kondisi Objektif & Standar & Kesimpulan \\
\hline 1 & $\begin{array}{l}\text { Landasan } \\
\text { Dasar } \\
\text { Pembelajaran } \\
\text { Pendekatan } \\
\text { Saintifik }\end{array}$ & $\begin{array}{l}\text { Mencantumkan } \\
\text { dasar program } \\
\text { pembelajaran } \\
\text { pendekatan } \\
\text { saintifik yang }\end{array}$ & $\begin{array}{l}\text { Program } \\
\text { pembelajaran } \\
\text { pendekatan saintifik } \\
\text { berdasarkan } \\
\text { Permendikbud }\end{array}$ & $\begin{array}{l}\text { Landasan dasar program } \\
\text { sesuai dengan peraturan } \\
\text { yang sudah ditetapkan } \\
\text { menurut kepala sekolah, } \\
\text { pengawas sekolah, dan guru }\end{array}$ \\
\hline & & disampaikan & nomor 103 tahun & kelas $\quad 4 \mathrm{C} \quad$ yaitu \\
\hline & & $\begin{array}{l}\text { responden } \\
\text { masih belum } \\
\text { ada yang sesuai. }\end{array}$ & 2014 pasal 2 ayat 7. & $\begin{array}{l}\text { Permendikbud nomor } 103 \\
\text { tahun 2014. Selain itu } \\
\text { responden lain, guru kelas } \\
4 \mathrm{~A} \text { dan } 2 \mathrm{~B} \text {, menyebutkan }\end{array}$ \\
\hline
\end{tabular}




\begin{tabular}{|c|c|c|c|c|}
\hline & & & & $\begin{array}{l}\text { dasar yang berbeda yaitu } \\
\text { Permendikbud nomor } 65 \\
\text { tahun } 2013 \text {. }\end{array}$ \\
\hline 2 & $\begin{array}{l}\text { Tujuan } \\
\text { Pembelajaran } \\
\text { Pendekatan } \\
\text { Saintifik }\end{array}$ & $\begin{array}{l}\text { Tujuan program } \\
\text { masih belum } \\
\text { operasional. }\end{array}$ & $\begin{array}{lr}\text { Tujuan } & \text { program } \\
\text { dijelaskan } & \text { secara } \\
\text { operasional, } & \\
\text { terperinci, dan sesuai } \\
\text { dengan landasan } \\
\text { program. }\end{array}$ & $\begin{array}{l}\text { Tujuan program sudah } \\
\text { sesuai dengan landasan, } \\
\text { namun masih belum jelas } \\
\text { dan merinci tujuan } \\
\text { operasional yang ingin } \\
\text { dicapai siswa. }\end{array}$ \\
\hline 3 & $\begin{array}{l}\text { Manfaat } \\
\text { Pembelajaran } \\
\text { Pendekatan } \\
\text { Saintifik }\end{array}$ & $\begin{array}{l}\text { Manfaat } \\
\text { program terasa } \\
\text { oleh siswa pada } \\
\text { khususnya, oleh } \\
\text { guru dan pihak } \\
\text { sekolah pada } \\
\text { umumnya. }\end{array}$ & $\begin{array}{l}\text { Manfaat program } \\
\text { sesuai dengan } \\
\text { program yang telah } \\
\text { ditentukan. }\end{array}$ & $\begin{array}{l}\text { MAnfaat program ini } \\
\text { terlihat dan dapat } \\
\text { dirasakan perubahannya } \\
\text { oleh siswa, siswa mampu } \\
\text { menciptakan pembelajaran } \\
\text { yang aktif kreatif, dan } \\
\text { menyenangkan. }\end{array}$ \\
\hline 4 & $\begin{array}{l}\text { Sasaran } \\
\text { Pembelajaran } \\
\text { Penekatan } \\
\text { Saintifik }\end{array}$ & $\begin{array}{l}\text { Sasaran } \\
\text { program masih } \\
\text { belum jelas dan } \\
\text { terperinci } \\
\text { tahapannya. }\end{array}$ & $\begin{array}{l}\text { Sasaran program } \\
\text { sesuai dengan tujuan } \\
\text { program. }\end{array}$ & $\begin{array}{l}\text { Sasaran yang ingin dicapai } \\
\text { masih belum optimal } \\
\text { karena masih ada yang } \\
\text { belum focus mencapai } \\
\text { target sasaran program } \\
\text { pembelajaran pendekatan } \\
\text { saintifik. }\end{array}$ \\
\hline 5 & $\begin{array}{l}\text { Sumber Daya } \\
\text { Manusia } \\
\text { (Guru) }\end{array}$ & $\begin{array}{l}\text { Terdapat nama- } \\
\text { nama SDM atau } \\
\text { guru sesuai } \\
\text { dengan } \\
\text { kualitasnya. }\end{array}$ & $\begin{array}{l}\text { Tersedia SDM yang } \\
\text { terlibat } \\
\text { professional. }\end{array}$ & $\begin{array}{l}\text { SDM atau guru sudah } \\
\text { dipersiapkan dan dilatih, } \\
100 \% \text { guru sudah memadai. }\end{array}$ \\
\hline 6 & $\begin{array}{l}\text { Sarana } \\
\text { Prasarana } \\
\text { Pembelajaran } \\
\text { Pendekatan } \\
\text { Saintifik }\end{array}$ & $\begin{array}{l}\text { Dapat } \\
\text { menunjang } \\
\text { pembelajaran } \\
\text { pendekatan } \\
\text { saintifik. }\end{array}$ & $\begin{array}{l}\text { Tersedia } \\
\text { baik. }\end{array}$ & 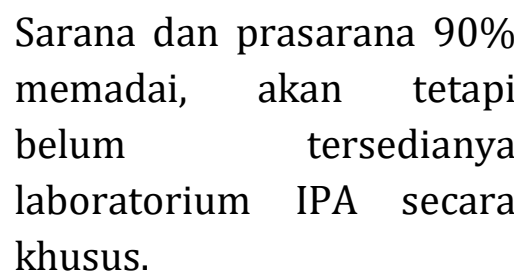 \\
\hline
\end{tabular}

\section{Aspek Proses (Transaction) Evaluasi Program Pembelajaran Saintifik}

Hasil evaluasi pada aspek proses terdiri dari perlengkapan administrasi dan proses berlangsungnya dimulai dari kegiatan pendahuluan, kegiatan inti, dan kegiatan penutup.
Administrasi Pendekatan Saintifik

Salah satu hal penting yang harus dipersiapkan sebelum kegiatan belajar berlangsung. Berdasarkan hasil wawancara kepala sekolah dan guru bahwa administrasi yang harus dipersiapkan terdiri atas: (1) ketersediaan silabus 
pembelajaran; (2) ketersediaan rencana program pembelajaran (RPP);

ketersediaan program semester; (4) ketersediaan program tahunan (PROTA), ketersediaan program semester (PROMES), ketersediaan buku nilai siswa. 100\% guru sudah melaksanakan administrasi pembelajaran pendekatan saintifik. Kepala sekolah mengevaluasi dan merevisi terhadap administrasi guru, minimal satu bulan sekali, bukan hanya administrasi guru kepala sekolah juga melakukan penilaian kinerja guru berupa monitoring proses belajar mengajar di kelas. Begitupun dengan pengawas sekolah melakukan pengawasan terhadap SDIT Raudlatul Jannah 1 bulan seklai atau sesuai kebutuhan (insidental).

\section{Proses Pelaksanaan Pembelajaran Pendekatan Saintifik}

Diambil dari hasil observasi guru dan siswa proses pelaksanaannya terdiri dari tiga kegiatan pokok yaitu kegiatan pemanasan, kegiatan isi, dan kegiatan pendinginan. Pada kegiatan pendahuluan, mencakup berdoa sebelum belajar, menyiapkan alat tulis, pengulangan pelajaran yang telah dipelajari atau ukuran pada tingkatan mana pengetahuan siswa dalam pelajaran yang akan dipelajari selanjutnya/apersepsi.

Kegiatan inti mencakup kegiatan memerhatikan seksama dalam pembelajaran, terdapat kegiatan menanya dalam pembelajaran, terdapat kegiatan mengumpulkan informasi/mencoba dalam pembelajaran, terdapat kegiatan mengasosiasi/menalar dalam pembelajaran, dan terdapat kegiatan mengkomunikasikan dalam pembelajaran. Adapun kegiatan penutup mencakup penilaian sikap, penilaian produk, dan penilaian keterampilan. $75 \%$ guru melaksanakan proses pembelajaran pendekatan saintifik, hasil ini sesuai dengan penelitian yang dilakukan oleh Wulandari (2016). Karena dalam kenyataannya berlandaskan hasil observasi guru masih ada guru yang belum melaksanakan prosedur dengan baik. Sedangkan di dalam kenyataannya berdasarkan observasi, $50 \%$ siswa melaksanakan pembelajaran pendekatan saintifik dengan baik.

Hal ini dikarenakan masih ada siswa yang belum mengerti dan memahami sehingga siswa malas dalam belajar dan ada juga siswa yang menyatakan siswa tersebut lebih senang belajar di dalam kelas untuk memperoleh tingkat konsentrasi yang lebih tinggi, ini dikarenakan pembiasaan orang tua di rumah yang tidak memberikan kesempatan belajar kepada siswa sehingga berpengaruh terhadap siswa kurang proaktif dalam pembelajaran.

Tabel 6 Perbandingan kondisi objektif dan kriteria aspek proses program pembelajaran pendekatan saintifik

\begin{tabular}{llllrlrl}
\hline No & Indikator & \multicolumn{1}{c}{ Kondisi } & \multicolumn{2}{c}{ Kriteria } & \multicolumn{2}{c}{ Kesimpulan } \\
& & \multicolumn{1}{c}{ Objektif } & & & \\
\hline 1 & Administrasi & Administrasi & Administrasi & sesuai & $100 \%$ & guru & memiliki \\
& Pembelajaran & pembelajaran & yang telah ditetapkan, administrasi & \\
& & pendekatan & tersedianya & silabus, pembelajaran & karena \\
& & saintifik & RPP, Promes, Prota dan & itu & merupakan \\
& & lengkap. & buku nilai. & & kewajiban dan adanya
\end{tabular}




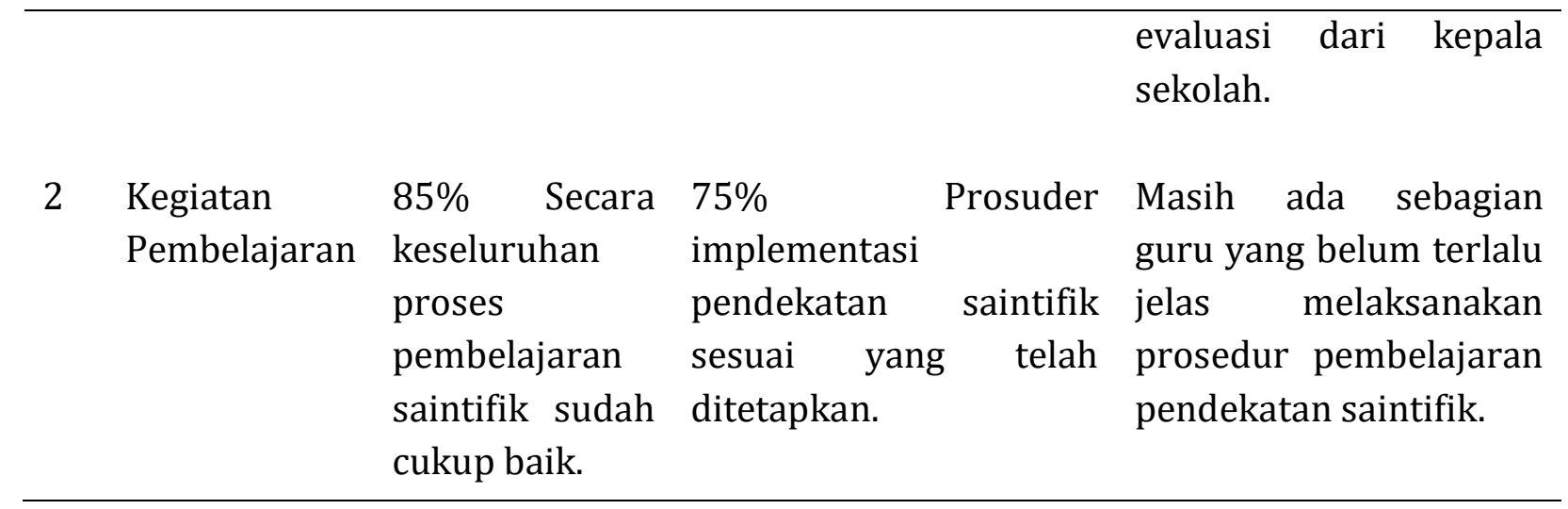

Sebagian besar guru melaksanakan indikator sesuai dengan Tabel 6, dari 4 guru yang diobservasi. Hal ini disebabkan masih ada guru belum terlalu paham terhadap pembelajaran pendekatan saintifik. Guru tersebut tidak aktif mencari dan mendalami pendekatan pembelajaran saintifik tersebut. Begitupun pengaruh lain berkaitan dengan pengalaman mengajar guru terhadap praktik guru dalam mengimplementasikannya. Karena guru yang belum terlalu paham adalah guru yang baru mengajar, atau guru tersebut mengajar kurang lebih baru 2 tahun. Sehingga pengalaman dalam aplikasi pendidikan secara universal dan spesifik dalam pembelajaran pendekatan saintifik tidak begitu luas. Adapun Perbandingan kondisi objektif dan kriteria aspek proses program pembelajaran pendekatan saintifik terdapat pada Tabel 6.

\section{Aspek Keluaran (Output) Evaluasi Program Pembelajaran Saintifik}

Hasil evaluasi terhadap aspek keluaran program terdiri dari keluaran jangka pendek yaitu dilihat dari pencapaian hasil belajar siswa yang menggunakan pembelajaran pendekatan saintifik yang terdiri dari kemampuan kognitif siswa mencapai KKM, rata-rata nilai nilai ujian kenaikan kelas siswa baik, dan ketercapaian ranah afektif/sikap siswa juga baik.

\section{Kriteria Ketuntasan Minimal Siswa}

Pencapaian rata-rata KKM siswa baik dengan rincian KKM sesuai yang telah disepakati sekolah, yaitu: (1) Mata pelajaran Bahasa Indonesia kelas 1 C KKMnya adalah 75; (2) Mata pelajaran Matematika kelas $1 \mathrm{~B}$ KKMnya adalah 70; (3) Mata pelajaran IPS kelas 4 A KKMnya adalah 75; dan (4) Mata pelajaran IPA KKMnya adalah 75.

Berdasarkan data yang dikumpulkan dari guru pencapaian rata-rata siswa kelas $1 \mathrm{~B}$ mapel MTK mencapai 90\%, pencapaian rata-rata siswa kelas $1 \mathrm{C}$ mapel $\mathrm{BI}$ mencapai $85 \%$, pencapaian rata-rata siswa kelas $4 \mathrm{~A}$ bidang studi IPS mencapai 100\%, pencapaian rata-rata siswa kelas $4 \mathrm{C}$ Bidang studi Ilmu Pengetahuan Alam mencapai 80\%. Secara keseluruhan pencapaian KKM siswa baik di atas rata-rata, hasilnya diperlihatkan pada Gambar 2.

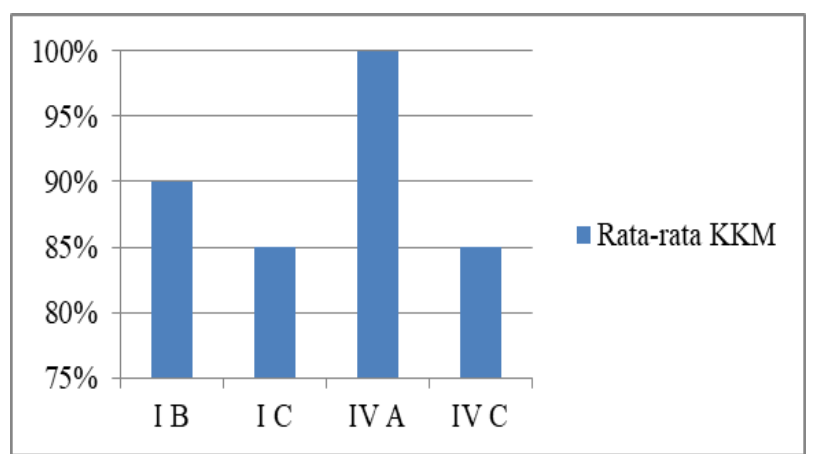

Gambar 2 Rata-rata KKM siswa berdasarkan hasil yang diperoleh dari guru

Dari KKM ini dipaparkan dan disimpulkan bahwa nilai rata-rata UKK 
siswa juga baik. Siswa seluruhnya mencapai kriteria yang ditetapkan. Adapun untuk yang memiliki kecerdasan di bawah ratarata di SDIT Raudlatul Jannah sebelum siswa masuk mendapat kelas kemudian diadakan psikotes untuk melihat gaya belajar siswa, kecerdasan siswa, dan potensi lainnya. Tetapi bukan untuk menentukan siswa yang dapat melanjutkan atau tidak, karena dalam jenjang dikdas tidak diperbolehkan menggunakan tes masuk bagi siswa. Follow up dari tes psikotes ini yaitu jika ada siswa yang memiliki kemampuan di bawah rata-rata siswa lainnya maka akan diadakan trapi khusus dan berkala dengan scedule yang telah dijadwalkan sehingga siswa tersebut mampu menyusul keterlambatan dan dapat berjalan bersama siswa yang lainnya.

\section{Ketercapaian Ranah Afektif Siswa}

Hasil evaluasi dari keluaran program ini adalah tercapainya ranah afektif siswa. Selain nilai mutu yang didapatkan siswa, yang lebih penting lagi yaitu bagaimana menciptakan sikap atau karakter siswa selaras dengan Allah SWT. Aspek ini dilihat dari keseharian siswa dalam melaksanakan program.

Berdasarkan hasil observasi dan wawancara siswa di setiap kelas, siswa menunjukan sikap yang baik dimulai dari cara berkomunikasi dengan guru dan teman, siswa mampu bersikap terbuka atau menyampaiakan pendapat, mampu bekerjasama dalam kelompok belajarnya, dan siswa berani menampakkan diri di khalayak ramai dengan mengkomunikasikan hasil belajar atau hasil karyanya. Siswa juga sadar untuk lebih aktif, senang, dan menyatakan bahwa hasil belajarnya lebih meningkatkan kualitasnya.

Berdasarkan aspek keluaran ini siswa SDIT Raudlatul Jannah bukan hanya mampu mendapatkan hasil yang maksimal tetapi juga para lulusannya banyak diterima di sekolah negeri dan sekolah swasta terkenal di jenjang berikutnya, dan para lulusannya mampu berkompetensi dengan baik (berprestasi).

Tabel 7 Perbandingan kondisi objektif dan kriteria aspek keluaran pembelajaran pendekatan saintifik

\begin{tabular}{|c|c|c|c|c|}
\hline No & Indikator & Kondisi Objektif & Kriteria & Kesimpulan \\
\hline 1 & $\begin{array}{l}\text { Kemampuan } \\
\text { kognitif } \\
\text { siswa }\end{array}$ & $\begin{array}{lr}\text { Rata-rata } & \text { sebagian } \\
\text { besar } & \text { siswa } \\
\text { mencapai } & \text { KKM } \\
\text { yang } & \text { telah } \\
\text { ditentukan. } & \end{array}$ & $\begin{array}{l}\text { KKM siswa harus sesuai } \\
\text { yang telah ditentukan } \\
\text { sekolah, yaitu: (1) Mata } \\
\text { pelajaran } \\
\text { Indonesia kelas } 1 \mathrm{C} \\
\text { KKMnya adalah } 75 ; \text { (2) } \\
\text { Mata pelajaran } \\
\text { Matematika kelas 1B } \\
\text { KKMnya adalah 70; (3) } \\
\text { Mata pelajaran IPS kelas } \\
\text { 4A KKMnya adalah 75; } \\
\text { dan (4) Mata pelajran IPA } \\
\text { KKMnya adalah 75. }\end{array}$ & $\begin{array}{l}\text { 90\% siswa mencapai } \\
\text { KKM pada mata } \\
\text { pelajaran } \\
\text { Matematika, } 85 \% \\
\text { siswa mencapai KKM } \\
\text { pada mata pelajaran } \\
\text { Bahasa Indonesia, } \\
\text { 100\% siswa } \\
\text { mencapai KKM pada } \\
\text { mata pelajaran IPS, } \\
\text { 80\% siswa mencapai } \\
\text { KKM pada mata } \\
\text { pelajaran IPS. }\end{array}$ \\
\hline
\end{tabular}




$\begin{array}{llrlrl}\text { Ketercapaian } & \text { siswa bersikap } & 100 \% \text { siswa harus } & 90 \% \text { siswa memiliki } \\ \text { ranah afektif } & \text { baik, siswa aktif } & \text { menunjukan afektif yang } & \text { afektif yang baik, } \\ \text { siswa } & \text { belajar, } & \text { mau baik. } & \text { karena masih ada } \\ & \text { bertanya, mampu } & \text { sebagian siswa yang } \\ & \text { bekerja sama dan } & \text { tertutup (introfert). } \\ & \text { berani tampil di } & \end{array}$

\section{KESIMPULAN DAN IMPLIKASI}

\section{Kesimpulan}

Berdasarkan analisa dan pembahasan yang disampaikan detail sebelumnya, dapat diambil benang merahnya bahwa pelaksanaan program pembelajaran pendekatan saintifik di SDIT Raudlatul Jannah secara umum sudah berjalan baik. Namun masih perlu pantauan dalam beberapa aspek agar sanggup mewariskan manfaat yang komprehensif dan target yang tepat. Sehingga niat yang dipatrikan juga bisa segera terealisasi. Program pembelajaran pendekatan saintifik di SDIT Raudlatul Jannah dalam implementasi kurikulum 2013 menjadi salah satu jalan pintas dalam meningkatkan pendidikan di Indonesia khususnya pendidikan tingkat Sekolah Dasar.

Hasil dari pelaksanaan program yaitu: (1) Aspek konteks (Antecedent), landasan atau dasar pelaksanaan program sejalan dengan Permendikbud No 103 tahun 2014 pasal 2 ayat 7; (2) Aspek proses (transaction), hasil evaluasi terhadap kesesuaian program pembelajaran pendekatan saintifik di SDIT Raudlatul Jannah 85\% sudah memenuhi kriteria. Dalam pembagian manajemen persiapan program sudah baik. Kemudian pada bagian implementasi prosedur program dapat disimpulkan umumnya cukup baik karena masih ada separuh guru yang belum melaksanakan prosedur dengan baik dan benar. Untuk pembelajaran di kelas siswa bisa mengikuti intruksi guru tetapi belum memuaskan karena masih ada siswa yang berusaha mengikuti pembelajaran dengan maksimal; (3) Aspek keluaran (output), hasil evaluasi terhadap keluaran program yaitu: hasil evaluasi terhadap nilai KKM siswa pada mata pelajaran yang dievaluasi diberi predikat baik, hasil evaluasi terhadap nilai ujian kenaikan kelas siswa baik, hasil evaluasi ranah afektif siswa ini cukup baik karena masih ada siswa yang harus terus diingatkan dalam bersikap baik kepada guru ataupun kepada temantemannya.

\section{Implikasi}

Hal-hal yang mendukung program yaitu adanya pelatihan guru, fasilitas yang memadai, lingkungan belajar sebagai sumber belajar dan adanya dukungan dari pihak luar sekolah yaitu orang tua, keluarga dan masyarakat. Namun selain itu ada juga faktor penghalang yang menyebabkan program sulit untuk mencapai optimal yaitu diantaranya sering berubahnya kebijakan pendidikan, beragamnya kemampuan siswa, sebahagian siswa kurang aktif memainkan peran dalam pembelajaran, dan yang terakhir keterlambatan buku-buku pembelajaran dari pemerintah. Mengacu pada hasil penelitian terhadap evaluasi program pembelajaran pendekatan saintifik di SDIT Raudlatul Jannah terdapat beberapa rekomendasi yang perlu dipertimbangkan 
agar program tersebut semakin baik dan berkualitas tinggi baik oleh kalangan akademisi maupun kalangan praktisi.

Kalangan Akademisi, beberapa hal yang bisa direkomendasikan dari untuk kalangan akademisi adalah: (1) Dapat ditindaklanjuti dengan penelitian lanjutan yang cenderung kepada evaluasi program penerimaan siswa baru dari tahap promosi. Perlu juga adanya rekrutmen hingga penerimaan dan penempatan siswa sehingga dapat diindikasi input sasaran program; (2) Konsep dan rumusan dari program ini perlu mendapat kajian lebih lanjut dari pakar pendidikan dan pemangku jabatan dalam mengatasi kesulitan atau kelemahan pada program khususnya dalam pengadaan buku atau bahan ajar serta pembinaan dan pendampingan guru.

Kalangan Praktisi, tersimpan beberapa rekomendasi untuk kalangan praktisi penyelenggara program yaitu SDIT Raudlatul Jannah: (1) Bagi lembaga pendidikan, sebagai perhitungan untuk lebih menekankan kebijakan tentang hal-hal yang berkaitan mengenai kegiatan program yang dapat meningkatkan kapabilitas guru, siswa serta sekolah itu sendiri; (2) Bagi para guru, dapat dijadikan masukan untuk perbaikan kedepannya dalam perencaanaan, penerapan dan evaluasi program di SDIT Raudlatul Jannah sehingga semakin cepat terarah harapan yang diimpikan.

\section{DAFTAR PUSTAKA}

Krisandi, A. D., \& Rusmawan. (2015). Kendala Guru Sekolah Dasar dalam Implementasi Kurikulum 2013. Cakrawala Pendidikan, 24(1), 457-467.

Kristiantari, M. R. (2014). Analisis Kesiapan Guru Sekolah Dasar dalam Mengimplementasikan Pembelajaran
Tematik Integratif Menyongsong Kurikulum 2013. Jurnal Pendidikan Indonesia, 3(2), 460-470.

Moleong, L. J. (2013). Metodologi Penelitian Kualitatif. Bandung: Rosdakarya.

Rudyanto, H. E. (2014). Model Discovery Learning dengan Pendekatan Saintifik Bermuatan Karakter untuk Meningkatkan Kemampuan Berpikir Kreatif. PREMIERE EDUCANDUM: Jurnal Pendidikan Dasar dan Pembelajaran, 4(1), 41-48.

Sesrita, A. (2017). Penggunaan Teknik Think-Pair-Share untuk Peningkatan Kompetensi Fisika. DIDAKTIKA TAUHIDI: Jurnal Pendidikan Guru Sekolah Dasar, 4(2), 140-158.

Siswanto, Kaniawati, I., \& Suhandi, A. (2014). Penerapan Model Pembelajaran Pembangkit Argumen Menggunakan Metode Saintifik Untuk Meningkatkan Kemampuan Kognitif Dan Keterampilan Berargumentasi Siswa. Indonesian Journal of Physics Education, 10(2), 104116.

Sugiyono. (2016). Metode Penelitian Kuantitatif, Kualitatif, dan R\&D. Bandung: Alfabeta.

Tureni, D. (2014). Penerapan Pendekatan Saintifik Berbasis Mind Mapping dalam Mata Kuliah Fisiologi Hewan pada Mahasiswa Pendidikan Biologi Universitas Tadulako. Jurnal Kreatif Tadulako, 17(2), 25-29.

Usman, H., \& Raharjo, N. E. (2013). Strategi Kepemimpinan

Pembelajaran Menyongsong Implementasi Kurikulum 2013. Cakrawala Pendidikan, 32(1), 1-13. Wangid, M. N., Mustadi, A., Erviana, V. Y., \& Arifin, S. (2014). Kesiapan Guru SD dalam Pelaksanaan Pembelajaran TematikIntegratif pada Kurikulum 2013 di DIY. Jurnal Prima Edukasia, 2(2), 175-182. 
Wibowo, A. (2017). Pengaruh Pendekatan Pembelajaran Matematika Realistik dan Saintifik Terhadap Prestasi Belajar, Kemampuan Penalaran Matematis dan Minat Belajar. Jurnal Riset Pendidikan Matematika, 4(1), 1-10.

Wirawan. (2012). Evaluasi Teori, Model, Standar, Aplikasi, dan Profesi. Jakarta: Rajawali Pers.
Wulandari, R. W., \& Mundilarto. (2016). Kompetensi Pedagogik dan Profesional Guru Fisika dalam Melaksanakan Pendekatan Saintifik di SMAN Sleman. Jurnal Pendidikan Fisika dan Keilmuan (JPFK), 2(2), 92-104. 